\title{
EDITORIAL OPEN Asthma still kills: little change over five decades
}

npj Primary Care Respiratory Medicine (2014) 24, 14029; doi:10.1038/npjpcrm.2014.29; published online 10 July 2014

The report of the UK National Review of Asthma Deaths (NRAD), ${ }^{1}$ the largest prospective study of its kind, was published recently on World Asthma Day 2014.

This was a confidential enquiry conducted by the Royal College of Physicians on behalf of the Health Quality Improvement Partnership in the UK. Of the 3,544 UK deaths with a mention of asthma on the death certificate between February 2012 and January 2013, 900 cases were included for reviewing. After excluding $39 \%$ of cases based on the clinical record and the opinion of the attending clinicians, 276/900 (31\%) with sufficient available data were considered in detail by 174 primary and secondary care clinicians at 37 enquiry panel meetings.

Major potentially preventable factors were identified in $67 \%$ of the 195 cases, where the panel concluded that the patient had died from asthma. Clearly, recommendations from previous asthma death studies have not been applied; many of these preventable factors have been identified previously, both in the UK $^{2-6}$ and elsewhere in the world., ${ }^{7,8}$ Outcomes could have been different had asthma guidelines ${ }^{9,10}$ been implemented. While some people have such severe asthma that death may not be preventable despite implementation of asthma guidelines, the outcome in many of the NRAD cases may have been different had the clinicians involved taken an alternative approach-certainly, the NRAD identified a number of cases where opportunities were missed during consultations for other medical problems. Examples of these included failure to recognise and take appropriate action in cases where people with asthma were collecting excess numbers of reliever inhalers or insufficient preventer (controller inhalers), and failure to follow up 13 of the 19 (68\%) cases who had been discharged from hospital following admission for acute asthma, or the $40 / 195$ (21\%) cases known to have attended the Emergency Department for acute asthma in the year before death.

The recent evidence-based, practical update of the Global Initiative for Asthma (GINA) guideline ${ }^{9}$ may help respiratory leaders in providing front-line clinicians (in primary and secondary care) with the guidance and tools needed to provide good asthma care. Particularly relevant to the findings of the UK NRAD is the section in GINA emphasising that despite having good current asthma control, patients may still be at risk of having future lifethreatening asthma attacks.

The panellists identified accuracy of diagnosis (of asthma and of the cause of death) as a problem. Eighty-one (29\%) of the deaths in the 276 cases considered by the enquiry panel were not considered to be due to asthma. Furthermore, in 27 cases (10\%) there was not sufficient evidence in the records to confirm that the patient actually had asthma. These findings, which suggest that UK national statistics based on death certification probably overestimate asthma death rates, ${ }^{6}$ may partly explain why reported UK asthma death rates $(1.47 / 100,000)$ are higher when compared with the rest of Europe, for example in the Netherlands $(0.31 / 100,000)^{11}$. Higher UK figures may also be explained by country variation in completion of death certificates, the application of the WHO ICD algorithm in ascribing the underlying cause of death, ${ }^{12}$ as well as differences in diagnostic practice and health-care delivery across the primary/secondary care interface. Any underestimate of asthma death rates in the UK may also be offset as a result of incorrectly ascribing asthma deaths to other diseases such as chronic obstructive pulmonary disease (COPD); a number of cases assessed by the NRAD panel had chronic asthma with fixed airflow obstruction, and therefore cases meeting these criteria and allocated an ICD code for COPD will have been excluded from the NRAD.

According to the ERS White book, ${ }^{11}$ UK hospital admission rates for adult asthma rank as the third highest in Europe (Slovakia and Spain being first and second) and therefore the NRAD finding of failure to ensure adequate hospital discharge planning and followup may also influence the relatively high asthma death rates.

To those of us in primary care who have been working for the last four decades to improve asthma care, ${ }^{13}$ the findings of the UK NRAD are deeply disturbing and profoundly disappointing. The results of this report demand urgent action to reflect upon and improve care for people with asthma, with the aim of reducing preventable asthma attacks and potentially avoidable deaths. Readers of this journal are likely to be at the forefront of asthma research, as well as being dedicated to the implementation of evidence-based medicine. We have nearly 50 years of evidence regarding potentially preventable features associated with asthma deaths, and no one wants to see another report in 20 years' time detailing potentially preventable factors in the management of people who die from asthma.

The NRAD report made 19 clear recommendations for change. ${ }^{1}$ Successful implementation of these will depend upon co-operation and collaboration between patients, their carers and clinicians, as well as first responders, pharmacists, commissioners and policy makers. While the NRAD reported on cases managed in the UK, there are lessons to be learned for those caring for people with asthma worldwide. Doctors and nurses need to work together with their patients to develop agreed personal asthma action plans so that all have a clear understanding of the medication, are able to recognise danger signs and know when to call for help. Clinicians could start by reflecting on the management of their own patients who have suffered asthma attacks or died from asthma, evaluating the quality of care against standards set in national and international guidelines. A formal process of significant event analysis, with a discussion of findings among peers and subsequent appropriate action could provide a suitable methodology for assessing these cases. ${ }^{14}$ Commissioners of care and policy makers could start by addressing and implementing those recommendations of the NRAD that are relevant for them. This would include ensuring appropriate training, delegation and provision of resources to ensure a comprehensive care pathway for people with asthma across the primary-secondary care interface.

\section{ACKNOWLEDGEMENTS}

This report was commissioned by the Healthcare Quality Improvement Partnership (HQIP) on behalf of NHS England, NHS Wales, the Health and Social Care Division of the Scottish Government, and the Northern Ireland Department of Health, Social Services and Public Safety (DHSSPS). The report was delivered by the Clinical Effectiveness and Evaluation Unit (CEEU) of the Clinical Standards Department at the Royal College of Physicians (RCP). I thank the core NRAD team: Rachael Andrews, Hannah Evans, Rosie Houston, Navin Puri and Laura Searle.

\section{COMPETING INTERESTS}

The author is Editor Emeritus of npj Primary Care Respiratory Medicine, but was not involved in the editorial review of, nor in the decision to publish, this article. 


\section{Mark L Levy ${ }^{1,2}$ \\ ${ }^{1}$ Clinical Standards Department-Clinical Effectiveness and Evaluation Unit (CEEU), London, UK and \\ ${ }^{2}$ Clinical Lead for the National Review of Asthma Deaths (NRAD), 2011-2014, Royal College of Physicians, London, UK Correspondence: ML Levy (marklevy@animalswild.com)}

\section{REFERENCES}

1 Royal College of Physicians. Why asthma still kills: the National Review of Asthma Deaths (NRAD) Confidential Enquiry report. Royal College of Physicians: London, 2014, Available from http://www.rcplondon.ac.uk/sites/default/files/why-asthmastill-kills-full-report.pdf.

2 Hills A, Sommer AR, Adelstein AM. Death from asthma in two regions of England. Br Med J 1982; 285: 1251-1255.

3 Fletcher HJ, Ibrahim SA, Speight N. Survey of asthma deaths in the Northern region, 1970-85. Arch Dis Childhood 1990; 65: 163-167.

4 Bucknall CE, Slack R, Godley CC, Mackay TW, Wright SC. Scottish Confidential Inquiry into Asthma Deaths (SCIAD), 1994-6. Thorax 1999; 54: 978-984.

5 Anagnostou K, Harrison B, lles R, Nasser S. Risk factors for childhood asthma deaths from the UK Eastern Region Confidential Enquiry 2001-2006. Prim Care Respir J 2012; 21: 71-77.

6 Harrison B, Stephenson P, Mohan G, Nasser S. An ongoing confidential enquiry into asthma deaths in the Eastern Region of the UK, 2001-2003. Prim Care Respir $J$ 2005; 14: 303-313.

7 Asthma Mortality Task Force. Recommendations of the Asthma Mortality Task Force. J Allergy Clin Immunol 1987; 80(3 Pt 2): 364-366.
8 Rea HH, Scragg R, Jackson R, Beaglehole R, Fenwick J, Sutherland DC. A casecontrol study of deaths from asthma. Thorax 1986; 41: 833-839.

9 Global Initiative for Asthma (GINA). The global strategy for asthma management and prevention, 2012. Available from http://www.ginasthma.org.

10 British Thoracic Society, Scottish Intercollegiate Guidelines Network. British guideline on the management of asthma. Thorax 2008 (revised January 2012);63 (Suppl 4): iv1-iv121.

11 European Respiratory Society. European Lung White Book, 2013. Available from http://www.erswhitebook.org/.

12 World Health Organisation. The International Classification of Diseases (ICD), 2013 Available from http://www.who.int/classifications/icd/en/.

13 Levy ML, Stephenson P, Barritt P, Bellamy D, Haughney J, Hilton S et al. The UK General Practice Airways Group (GPIAG): its formation, development, and influence on the management of asthma and other respiratory diseases over the last twenty years. Prim Care Respir J 2007; 16: 132-139.

14 NHS England. Significant Event Audit, 2008. Available from http://www.nrls.npsa. nhs.uk/resources/patient-safety-topics/human-factors-patient-safety-culture/? entryid45 $=61500 \& p=2$ (accessed 13 January 2014)

\section{c) (1) $९$}

This work is licensed under a Creative Commons AttributionNonCommercial-NoDerivatives 4.0 International License. The images or other third party material in this article are included in the article's Creative Commons license, unless indicated otherwise in the credit line; if the material is not included under the Creative Commons license, users will need to obtain permission from the license holder to reproduce the material. To view a copy of this license, visit http:// creativecommons.org/licenses/by-nc-nd/4.0/ 